The Journal of Animal \& Plant Sciences, 30(4): 2020, Page: 895-904

ISSN (print): 1018-7081; ISSN (online): 2309-8694

\title{
A HIGH GENETIC SIMILARITY AMONG THE SELECTED MANGO (MANGIFERA INDICA L.) GENOTYPES-CULTIVARS DEMONSTRATED BY SSR FINGERPRINTING
} ASSAY

\author{
I. A. Rajwana ${ }^{1}$, T. Shaheen ${ }^{2}$, A. U. Malik3 ${ }^{4}$, A. S. Khan ${ }^{3}$, Mahmood-ur-Rahman $^{2}$, M. A. Iqbal ${ }^{4,5}$, Y. Zafar ${ }^{5}$ and \\ Mehboob-ur-Rahman ${ }^{5}$ \\ ${ }^{1}$ Department of Horticulture, Muhammad Nawaz Shareef University of Agriculture, Multan, Pakistan; \\ ${ }^{2}$ Department of Bioinformatics and Biotechnology, GC University Allama Iqbal Road, Faisalabad-38000, Pakistan \\ ${ }^{3}$ Institute of Horticultural Sciences, University of Agriculture, Faisalabad, Pakistan \\ ${ }^{4}$ Department of Biotechnology, University of Okara, Pakistan \\ ${ }^{5}$ Plant Genomics and Molecular Breeding Laboratory, Agricultural Biotechnology Division, National Institute of \\ Biotechnology and Genetic Engineering, Faisalabad, Pakistan \\ *Corresponding author's Email: tayaba_pgmb@yahoo.com
}

\begin{abstract}
Mango (Mangifera indica L.) is one of the most important fruit crops worldwide. Mango has a long history of cultivation in Indo-Pak region which resulted in the development of novel regional germplasm as well as many famous mango cultivars. For sustaining the mango production especially in the present scenario of changing climate, it is important to characterize and estimate the genetic divergence among the mango genotypes-cultivars germplasm. To the extent of our knowledge, little efforts have been made to explore the magnitude of genetic divergence among the mango genotypescultivars. In this study, the genetic diversity assessments among 32 including 25 local and 7 exotic genotype-cultivars have been calculated using thirty-five simple sequence repeat (SSR) markers. The most informative primer was found Micir-6 while the polymorphism information content (PIC) value of all SSRs was found low, i.e., 0.168 - 0.5. Genetic diversity ranged from $15 \%$ to $47 \%$ among cultivars with a mean value $30 \%$. The dissimilarity coefficients based unweighted pair group of arithmetic means (UPGMA) was used to make clusters. Mostly East Indian, North Indian and Pakistani cultivars were grouped in one cluster while South Indian and Florida cultivars in other according to the dendogram. The present study would help in taking proactive decision to buffer the spread of any epidemics and will also be helpful in initiating marker-assisted breeding program for developing cultivars with excellent genetics.
\end{abstract}

Keywords: Genetic Diversity, Indo-Pak, Mangifera indica L., SSR markers.

https://doi.org/10.36899/JAPS.2020.4.0105

Published online April 25, 2020

\section{INTRODUCTION}

Mango is the significant and prevalent fruit crop and important cash crop produced about $40 \mathrm{Mt}$ in 2012 , is mainly grown in subtropical and tropical areas worldwide (Fig. 1). It is an allopolyploid species and a member of family Anacardiaceae (Jha et al., 2010: Yamanaka et al., 2019). Mango is rich in germplasm diversity having approximately 1600 varieties distributed in the world (Panday et al., 1998; Yamanaka et al., 2019). Worldwide, more than $75 \%$ mango is produced in China, India, Thailand, Mexico, Pakistan and Indonesia (Viruel et al., 2005; Mitra 2016), while Pakistan is at fifth position in mango production (Maqbool and Malik, 2008; Baloch and Bibi, 2012).

In Pakistan, numerous biotic and abiotic factors resulted in the declined yield of mango. One important and recent risk to the Pakistan mango industry is the mango quick decline (Masood et al., 2011). One of the most important element for helping breeders for making crosses is genetic diversity. Thus it helps breeders for an improved selection of appropriate parents to generate new breeding cultivars. An extended selection output could be attained with a greater information about the range of genetic diversity or genetic similarity inside the germplasm resources (Chowdhury et al., 2002; Majumder et al., 2013). A wider genetic base provides the fruit crops with the ability to produce the high yield under different agro-climatic conditions and also contains the capacity to resist the infectious diseases (Abou-Ellail et al., 2014).

Furthermore, Variation for new assortments can be obtained from a rich germplasm (Rajwana et al., 2008, 2011; Ab Razak et al., 2019). Both categorization and assessment of the genetic diversity among varieties are most important factors to improve the quality of mango and sustainability in its production in the changing climate. In current years, a progressive utility of molecular genetic techniques using DNA-based analysis to depict and calculate genetic diversity and association among various genotypes, cultivars and advanced lines 
was observed (Ravishankar et al., 2015). Random amplified polymorphic DNA (RAPD) (Souza et al., 2011; Pruthvish and Chikkaswamy, 2016), restriction fragment length polymorphism (RFLP), inter-simple sequence repeats (Pandit et al., 2007; El Kheshin et al., 2016), simple sequence repeat (SSR) (Kumar et al., 2013; Oloka et al., 2015: Nazish et al., 2017) and amplified fragment length polymorphism (AFLP) (Galvez-Lopez et $a l ., 2009)$ are the mainly used DNA fingerprinting assays for the evaluation of genetic diversity between plant varieties (Rahman et al., 2002, 2008 and 2012). A number of genetic diversity studies in mango genotypescultivars were carried out using RAPD markers (Rajwana et al., 2008; Jena et al., 2010) which are handicapped due to their poor reproducibility. Simple sequence repeats (SSRs) are considered the most promising because of their abundance, reproducibility, informativeness, codominance in expression and robustness (Pejic et al., 1998; Hasan et al., 2006: Yamanaka et al., 2019; Ab Razak et al., 2019).

Historically, several important cultivarsgenotypes have been evolved in Pakistan. Indo-Pak to the Malay Peninsula in Southeast Asia is considered as area of origin of mango. It is also the center of diversity and evolution of mango because mango has been grown for more than 4000 years in this area (Yamanaka et al., 2019). Preliminary study about genetic diversity among the available gene pools in Pakistan would not only help the mango breeder of Pakistan but would also add useful genetic information for the international mango breeding community. Thus by the use of SSR markers, the current investigation was designed to measure the extent of genetic dissimilarity and or similarity between the different cultivars in Pakistan. The data obtained would pave the way for developing mango cultivars with improved genetics.

\section{MATERIALS AND METHODS}

Plant Materials: Total thirty-two commercial mango genotypes-cultivars sourced from various Research Institutes of Pakistan were included in the study. The morphological traits and geographical origin of genotypes-cultivars used in the current study is presented in Table -1 .

Plant DNA Extraction: Two to three days old, fresh leaves grown on the young emerging branches were excised for DNA extraction. The leaves were stored at $70^{\circ} \mathrm{C}$ (after washing with distilled water) in freezer until their use. A method (after doing slight modifications) proposed by Doyle and Doyle (1987) was used to extract total genomic DNA from each plant sample. Quality of the extracted genomic DNA was examined on $0.8 \%(\mathrm{w} / \mathrm{v})$ agarose gel. The quantity of the DNA was measured on
NanoDrop-1000 version 3.3.1 spectrophotometer (Nanodrop, USA).

Simple Sequence Repeat (SSR) Analysis: Thirty five SSR primer pairs selected from Micir and Mishrs series (Mishrs-1, Mishrs-4, Mishrs-21, Mishrs-22, Mishrs-39, Mishrs-44, Mishrs-37, Mishrs-34, Mishrs-33, Mishrs-36, Mishrs-48, Micir-1 to 6, Micir-8, Micir-9, Micir-11, Micir-12, Micir-14, Micir-16, Micir-18, Micir-20 to 22, Micir-24, Micir-25, Micir-29, Micir-30, Micir-33, Micir36, Micir-28, Micir-34) were randomly selected across the mango genome.

The PCR reaction mixture included the reagents (Fermentas) (10 X PCR Buffer $\left(\left(\mathrm{NH}_{4}\right)_{2} \mathrm{SO}_{4}+\mathrm{MgCl}_{2}\right)$, $\mathrm{MgCl}_{2} 50 \mathrm{mM}$, genomic DNA $2.0 \mu \mathrm{L}(30 \eta \mathrm{g} / \mu \mathrm{L}), 1.5 \mu \mathrm{L}$ of reverse and forward primer with a concentration of 30 $\eta \mathrm{g} / \mu \mathrm{L}$ each, $4.5 \mu \mathrm{L}$ of $0.2 \mathrm{Mm}$ of total $\mathrm{dNTP}_{\mathrm{s}}$, and $0.3 \mu \mathrm{L}$ Taq DNA polymerase ( 5 unit/ $\mu \mathrm{L})$. By adding $\mathrm{ddH}_{2} \mathrm{O}$ final volume was kept $20 \mu \mathrm{L}$.

Amplification was carried out in Eppendorf Mastercycler (Germany). The sequence of the programme in Mastercycler was as one initial cycle at $94^{\circ} \mathrm{C}$ for $5 \mathrm{~min}$, followed by 35 cycles (each cycle was programmed for denaturation for $30 \mathrm{~s}$ at $94^{\circ} \mathrm{C}$, annealing for $30 \mathrm{~s}$ at $55^{\circ} \mathrm{C}$ and extension for $1 \mathrm{~min}$ at $72^{\circ} \mathrm{C}$ ). One final temperature (extension) treatment at $72^{\circ} \mathrm{C}$ for 10 min was given, and tubes were immediately removed or hold at $4^{\circ} \mathrm{C}$. PCR amplicons were fractionated on $4.0 \%$ $(\mathrm{w} / \mathrm{v})$ high resolution metaphor agarose gel and visualized on ultraviolet trans-illuminator. Gel pictures were captured with a gel documentation system.

Data Analysis: Amplicon size was determined by comparing them by running a standard marker (Gene Ruler 100 bp DNA ladder plus, Fermentas, USA). These amplicons were rated ' 1 ' if the amplicon was present otherwise ' 0 '. Both types of amplicons i.e. reproducible amplicons were counted as polymorphic and monomorphic in the analysis. Some loci were considered as 'null' alleles as they could not be amplified even by repeating PCR reactions thrice in a few genotypes. The extent of diversity (Anderson et al.,, 1993) was measured by calculating PIC value for each SSR using the formula "PIC $=1-\Sigma \mathrm{P} i j^{2}$ ". Here, Pij represents the frequency of "jth" allele for the "ith" locus cumulated across all alleles for the locus.

The data was used to measure the extent of genetic similarity using the number of common amplicons (Nei and Li, 1979). The dendrogram of 32 mango genotypes-cultivars was generated using the dissimilarity coefficients by deploying UPGMA.

\section{RESULTS AND DISCUSSION}

This study was conducted to investigate intervarietal genetic diversity among 32 different mango cultivars using SSR markers. All SSRs produced 
amplifications in all cultivars-genotypes (Fig 2). Twentyeight primers $(80 \%)$ yielded polymorphic bands. Total 1386 amplification products were produced and majority were polymorphic. On average, each SSR produced 38 DNA amplicons. Overall, 11 (39.3\%) showed polymorphism because of amplification of alleles of diverse sizes, while $17(60.7 \%)$ were polymorphic because they produced null alleles in few genotypes.

On average 38 amplicons per primer were produced. In another study, relatively few amplicons were reported while using 16 primer pairs on 28 mango genotypes (Viruel and Hormaza, 2004). Twenty-eight (80\%) SSRs out of 35 were polymorphic depicting a high rate of polymorphism was similar to the findings of Kumar et al., (2013). The higher ratio of polymorphic primers can be attributed to hyper variable nature of the SSR markers (Zhang et al., 2014).

The range of PIC value was 0.5 (Micir 6) to 0.168 (Micir 16) with an average of 0.50. Micir 6 was the only highly informative marker with PIC value $(0.5$, Table 3). Ab Razak et al. (2019) found average PIC value 0.4585 during a study of genetic diversity of 116 mango genotypes using 20 polymorphic SSRs. The PIC value is an important factor which helps in choosing SSR markers to evaluate germplasm and gene tagging (Peng and Lapitan, 2004). Most informative SSRs can be selected with the help of PIC values and it is done by reducing the amount of SSR markers to calculate the genetic diversity (Tabassam et al., 2014), and can also enhance the potential of breeders for estimating the magnitude of genetic diversity and identification of varieties (Masi et al., 2013: Jain et al., 2004; Rajwana et al., 2008).

The inconsistency in PIC values for different SSR primers is primarily because of number of repeat units and length of the SSR locus, and nature of germplasm under investigation (Tabassam et al., 2014; Kebede et al., 2007; Liu et al., 2000a; Kalivas et al., 2011). Also the bottleneck in evolution-contributed largely by the selection imposed by the farmers and breeders is another reason for finding low PIC value for the SSR loci (Thuillet et al., 2004; Vigouroux et al., 2005; Tabassam et al., 2014) and the kind of DNA markers (Liu et al., 2000b; Gutierrez et al., 2002). Results of this study revealed a low PIC values [0.168 (Micir-16) to 0.5 (Micir-6)] for the markers used. The mean PIC value for Mishr and Micir primer series was 0.403 and 0.347 respectively, which was lesser than previous reports (Shareefa, 2000; Nayak, 2010). Particularly in Florida mango cultivars a minimum to medium PIC values of SSR markers were observed (Schnell, 2006). The lower PIC values can be one reason of low genetic diversity displayed in the used cultivars (Kumar et al., 2013).

The range of variation in the genetic dissimilarity coefficients amid different cultivarsgenotypes was from 0.15 to 0.47 with an average value of
0.30. Alphonso and Pope were found most genetically similar (85\%) while Chaunsa and New Sindhri were least similar (53\%) having 0.47 dissimilarity coefficient. In the whole experiment, Pope emerged as the maximum genetically similar genotype, showing 75\% similarity with all cultivars-genotypes whereas the most diverse genotype was Sufaid Chaunsa (35\% dissimilar or $65 \%$ genetically similar to the other genotypes-cultivars, Table 2 ). This study revealed a relatively great degree of genetic relatedness among the mango genotypes studied. The distribution and the geographical origin of the cultivars may be the one reason of this high level $(70 \%$ on average) of genetic similarity. There is intense need to expand the genetic base of germplasm to overcome this similarity (Bally et al., 1996). This high degree of genetic relatedness can be attributed to the convenience and usage of Chaunsa stones to develop nursery plants and further preferably unplanned seedling selection from the population. Furthermore, various cultivars like Sufaid Chaunsa and Kala Chaunsa are offshoots of Chaunsa because Chaunsa has been used as parent to develop new cultivars (Ahmad, 2007). Breeding programmes intensely need to have broad genetic base to minimize the dilemma of genetic similarity, which can be achieved by harnessing new cultivars in breeding programmes and amalgamation of local germplasm with exotic germplasm.

In current study, the minimum dissimilarity observed among the local cultivar Faiz Kareem and Taimuria is contrary to the earlier reports using RAPD assay (Rajwana et al., 2008) which supported that Faiz Kareem is a derivative of Anwar Ratole and Chaunsa. Type of markers to assess the genetic diversity can be responsible for this disagreement as SSR markers are more robust than RAPDs (Garcia et al., 2004). Moreover, validation of genealogy of Faiz Kareem need further extensive studies.

The dissimilarity matrix coefficients generated in the present study were used to develop a dendrogram using UPGMA cluster analysis (Fig. 3). The 32 genotypes-cultivars were grouped into two major clusters, ' $A$ ' and ' $B$ '. The cluster $A$ was further comprised of two sub-clusters ' $\mathrm{A}_{1}$ ' and ' $\mathrm{A}_{2}$ '. Eight cultivars including Taimooria, Faiz Kareem, Sobhey de Ting, Late Ratole No.12, Anwar Ratole, Sufaid Chaunsa, S.B. Chaunsa (known as Chaunsa commonly), and Kala Chaunsa were included in sub-cluster $A_{1}$. While eight cultivars including Alphonso, Sindhri, Pope, Fajri, Sensation, Langra, Malda, and Lahootia were present in sub-cluster $\mathrm{A}_{2}$.

Next major cluster, ' $\mathrm{B}$ ', was further divided into two sub-clusters ' $\mathrm{B}_{1}$ ' and ' $\mathrm{B}_{2}$ '. Sub-cluster ' $\mathrm{B}_{1}$ ' included eight cultivars Sanglakhi, Neelum, Kensington Pride, Haden, Maya, Yakta, Totapari and Collector. Seven cultivars in sub-cluster ' $\mathrm{B}_{2}$ ', including Dusehri, Tommy Atkins, Haider Shah, Began Palli, Zardalu, New Sindhri 
and Keitt showed a sister group relationship. Another cultivar Swarnarekha was also grouped in Cluster B, which was genetically distinct from the genotypescultivars grouped in sub-clusters ' $\mathrm{B}_{1}$ ' and ' $\mathrm{B}_{2}$ '.

In each sub-clusters of the cluster ' $A$ ', mango genotypes evolved in Pakistan, Northern Indian and North Eastern Indian origins grouped together. However, few Pakistani and Indian genotypes distributed in both the sub-clusters, indicating that these genotypes shared a common genetic origin. Sensation and Pope which are exotic cultivars were also grouped in cluster ' $A$ ' and is opposite to earlier studies (Rajwana et al., 2008) which indicates that these genotypes share common ancestry with the South Asian cultivars.

Majorly Florida and South Indian cultivars were included in Cluster 'B'. Keitt developed a sister group with Tommy Atkins in the sub-cluster B2 which can be attributed to their common geographical origin from
Florida and depicts sharing a common ancestor of these cultivars. Uniqueness of South Indian cultivars from other Indian cutivars was also illustrated by the finding that Swarnarekha a South Indian cultivar occupied distinct place in cluster B. Presence of cultivars of Florida (Haden, Keitt and Tommy Atkins) in the same group with Indian cultivars validate the previous findings (Schnell et al., 2006). Presence of Maya and Haden in a close sister group confirms the development of Maya from the Haden's seedling (Viruel et al., 2005). New Sindhri cultivar (Khan Garh, Pakistan) which is thought to be a variant of Sindhri (Tharparker, Pakistan) was grouped in cluster B, interestingly. Among the morphological features, the genotypes that produce Oblong or Ovate shaped fruit clustered in A. While in cluster B, mostly the genotypes-cultivars produce round or ovate-shaped, while other traits are not showing a clear trend in grouping.

Table-1. Mango cultivars used for SSR analysis and their morphological characters.

\begin{tabular}{|c|c|c|c|c|c|c|c|}
\hline $\begin{array}{l}\text { Sr. } \\
\text { No }\end{array}$ & Cultivar & Geographic origin & NLC & AFW & FS & Fiber & TSS \\
\hline 1 & Faiz Kareem & Multan, Pakistan & Yellowish green & 290 & Ovate Oblong & Absent & $25-26$ \\
\hline 2 & Anwar Ratole & Northern India & Yellowish green & 185 & Round Ovate & Scanty & $24-26$ \\
\hline 3 & Chaunsa & Northern India & Yellowish green & 350 & Oblong Ovate & Medium & $25-27$ \\
\hline 4 & Taimooria & Northern India & Yellowish green & 180 & Oblong & Scanty & $22-24$ \\
\hline 5 & Kala Chaunsa & Multan, Pakistan & Light brown & 300 & Oblong & Much & $25-27$ \\
\hline 6 & Sanglakhi & Northern India & Light brown & 400 & Round Ovate & Absent & $17-20$ \\
\hline 7 & Sufaid Chaunsa & Multan, Pakistan & Yellowish green & 500 & Oblong Ovate & Scanty & $24-26$ \\
\hline 8 & Neelum & Southern India & Light Green & 250 & Ovate & Low & $12-14$ \\
\hline 9 & Late Ratole No 12 & Multan, Pakistan & Dark green & 200 & Ovate & Medium & $16-17$ \\
\hline 10 & Alphonso & Western India & Medium green & 200 & Ovate to Cordate & Scanty & $21-23$ \\
\hline 11 & Langra & Northern India & Light Green & 350 & Ovate & Scanty & $20-21$ \\
\hline 12 & Yakta & Sindh, Pakistan & Lush Green & 400 & Ovalish oblong & Low & $19-20$ \\
\hline 13 & Dusehri & Northern India & Yellowish green & 190 & Oblong & Absent & $24-26$ \\
\hline 14 & Sindhri & Tharparker, Pakistan & Light brown & 450 & Oblong Ovate & Absent & $17-20$ \\
\hline 15 & Fajri & North Eastern India & Yellowish green & 550 & Oblong & Scanty & $24-26$ \\
\hline 16 & New Sindhri & Khan Garh, Pakistan & $\begin{array}{l}\text { Light green with } \\
\text { brownish ting }\end{array}$ & 400 & Narrowly ecliptic & Absent & $14-17$ \\
\hline 17 & Lahootia & Northern India & Yellowish green & 220 & Oblong Ovate & Scanty & $24-25$ \\
\hline 18 & Sobhey de Ting & $\begin{array}{l}\text { Muzaffargarh, } \\
\text { Pakistan }\end{array}$ & Yellowish green & 125 & Ovate Oblong & Scanty & $18-20$ \\
\hline 19 & Began Palli & Southern India & Light brown & 500 & Round Ovate & Scanty & $20-22$ \\
\hline 20 & Keitt & Florida, USA & Greenish & 300 & Round Ovate & Scanty & $17-19$ \\
\hline 21 & Tommy Atkins & Florida, USA & Light brown & 400 & Round Ovate & Scanty & $17-19$ \\
\hline 22 & Kensington Pride & Australia & Greenish & 345 & Round Ovate & Scanty & $18-20$ \\
\hline 23 & Maya & Israel & Greenish & 335 & Round Ovate & Scanty & $20-21$ \\
\hline 24 & Swarnarekha & Southern India & Greenish & 500 & Round Oblong & Scanty & $22-24$ \\
\hline 25 & Haider Shah & $\begin{array}{l}\text { Muzaffargarh, } \\
\text { Pakistan }\end{array}$ & Yellowish green & 125 & Ovate & Scanty & $22-24$ \\
\hline 26 & Totapari & Southern India & Medium green & 400 & Oblongish & Medium & $15-16$ \\
\hline 27 & Collector & Northern India & Yellowish green & 400 & Round Ovate & Medium & $17-19$ \\
\hline 28 & Zardalu & Eastern India & Greenish & 260 & Round Ovate & Scanty & $20-21$ \\
\hline 29 & Pope & Hawaii, USA & Brownish & 385 & Oblong Ovate & Scanty & $17-18$ \\
\hline 30 & Sensation & Florida, USA & Brownish green & 250 & Round Ovate & Scanty & $17-18$ \\
\hline 31 & Malda & India & Medium green & 250 & Broad oblongish & Scanty & $12-14$ \\
\hline 32 & Haden & Florida, USA & Medium green & 400 & Ovate & Low & $17-18$ \\
\hline
\end{tabular}

Where, NLC $=$ new leaf co

lor; $\mathrm{AFW}=$ average fruit weight; $\mathrm{FS}=$ fruit shape; $\mathrm{TSS}=$ total soluble solids. 
Table-2. Dissimilarity matrix of 32 mango genotypes-cultivars using 35 SSR primer pairs.

\begin{tabular}{|c|c|c|c|c|c|c|c|c|c|c|c|c|c|c|c|c|c|c|c|c|c|c|c|c|c|c|c|c|c|c|c|c|}
\hline & 1 & 2 & 3 & 4 & 5 & 6 & 7 & 8 & 9 & 10 & 11 & 12 & 13 & 14 & 15 & 16 & 17 & 18 & 19 & 20 & 21 & 22 & 23 & 24 & 25 & 26 & 27 & 28 & 29 & 30 & 31 & 32 \\
\hline 1 & 0 & & & & & & & & & & & & & & & & & & & & & & & & & & & & & & & \\
\hline 2 & 0.23 & 0 & & & & & & & & & & & & & & & & & & & & & & & & & & & & & & \\
\hline 3 & 0.23 & 0.33 & 0 & & & & & & & & & & & & & & & & & & & & & & & & & & & & & \\
\hline 4 & 0.17 & 0.23 & 0.23 & 0 & & & & & & & & & & & & & & & & & & & & & & & & & & & & \\
\hline 5 & 0.29 & 0.24 & 0.24 & 0.21 & 0 & & & & & & & & & & & & & & & & & & & & & & & & & & & \\
\hline 6 & 0.3 & 0.29 & 0.29 & 0.29 & 0.29 & 0 & & & & & & & & & & & & & & & & & & & & & & & & & & \\
\hline 7 & 0.26 & 0.3 & 0.21 & 0.3 & 0.24 & 0.29 & 0 & & & & & & & & & & & & & & & & & & & & & & & & & \\
\hline 8 & 0.26 & 0.27 & 0.33 & 0.3 & 0.3 & 0.29 & 0.3 & 0 & & & & & & & & & & & & & & & & & & & & & & & & \\
\hline 9 & 0.26 & 0.18 & 0.33 & 0.3 & 0.3 & 0.29 & 0.21 & 0.21 & 0 & & & & & & & & & & & & & & & & & & & & & & & \\
\hline 10 & 0.27 & 0.23 & 0.32 & 0.29 & 0.29 & 0.27 & 0.32 & 0.23 & 0.26 & 0 & & & & & & & & & & & & & & & & & & & & & & \\
\hline 11 & 0.27 & 0.32 & 0.29 & 0.32 & 0.38 & 0.33 & 0.29 & 0.29 & 0.29 & 0.27 & 0 & & & & & & & & & & & & & & & & & & & & & \\
\hline 12 & 0.29 & 0.21 & 0.42 & 0.27 & 0.24 & 0.38 & 0.3 & 0.27 & 0.24 & 0.32 & 0.32 & 0 & & & & & & & & & & & & & & & & & & & & \\
\hline 13 & 0.33 & 0.23 & 0.35 & 0.29 & 0.26 & 0.36 & 0.38 & 0.32 & 0.29 & 0.36 & 0.33 & 0.26 & 0 & & & & & & & & & & & & & & & & & & & \\
\hline 14 & 0.36 & 0.23 & 0.38 & 0.35 & 0.32 & 0.3 & 0.38 & 0.23 & 0.26 & 0.18 & 0.3 & 0.26 & 0.24 & 0 & & & & & & & & & & & & & & & & & & \\
\hline 15 & 0.26 & 0.3 & 0.27 & 0.27 & 0.33 & 0.32 & 0.33 & 0.24 & 0.27 & 0.23 & 0.26 & 0.3 & 0.26 & 0.26 & 0 & & & & & & & & & & & & & & & & & \\
\hline 16 & 0.33 & 0.29 & 0.47 & 0.29 & 0.41 & 0.39 & 0.5 & 0.26 & 0.32 & 0.33 & 0.39 & 0.32 & 0.3 & 0.18 & 0.29 & 0 & & & & & & & & & & & & & & & & \\
\hline 17 & 0.45 & 0.26 & 0.26 & 0.38 & 0.26 & 0.33 & 0.38 & 0.29 & 0.32 & 0.3 & 0.33 & 0.38 & 0.3 & 0.27 & 0.26 & 0.36 & 0 & & & & & & & & & & & & & & & \\
\hline 18 & 0.3 & 0.17 & 0.26 & 0.29 & 0.26 & 0.3 & 0.32 & 0.32 & 0.17 & 0.3 & 0.27 & 0.26 & 0.24 & 0.27 & 0.29 & 0.33 & 0.21 & 0 & & & & & & & & & & & & & & \\
\hline 19 & 0.38 & 0.36 & 0.36 & 0.36 & 0.42 & 0.29 & 0.39 & 0.33 & 0.39 & 0.41 & 0.29 & 0.42 & 0.29 & 0.35 & 0.3 & 0.32 & 0.35 & 0.32 & 0 & & & & & & & & & & & & & \\
\hline 20 & 0.32 & 0.33 & 0.33 & 0.33 & 0.36 & 0.32 & 0.39 & 0.24 & 0.36 & 0.29 & 0.29 & 0.39 & 0.29 & 0.29 & 0.21 & 0.29 & 0.32 & 0.32 & \begin{tabular}{|l|}
0.21 \\
\end{tabular} & 0 & & & & & & & & & & & & \\
\hline 21 & 0.41 & 0.27 & 0.42 & 0.27 & 0.36 & 0.29 & 0.42 & 0.27 & 0.3 & 0.35 & 0.35 & 0.33 & 0.26 & 0.23 & 0.3 & 0.29 & 0.32 & 0.32 & \begin{tabular}{l|}
0.27 \\
\end{tabular} & 0.24 & 0 & & & & & & & & & & & \\
\hline 22 & 0.41 & 0.3 & 0.36 & 0.33 & 0.27 & 0.2 & 0.42 & 0.27 & 0.3 & 0.32 & 0.41 & 0.3 & 0.26 & 0.29 & 0.33 & 0.35 & 0.32 & \begin{tabular}{|c|}
0.23 \\
\end{tabular} & 0.24 & 0.3 & 0.24 & 0 & & & & & & & & & & \\
\hline 23 & 0.39 & 0.29 & 0.35 & 0.29 & 0.29 & 0.24 & 0.32 & 0.26 & 0.32 & 0.33 & 0.42 & 0.32 & 0.3 & 0.27 & 0.29 & 0.27 & 0.33 & \begin{tabular}{|l|}
0.33 \\
\end{tabular} & \begin{tabular}{l|}
0.32 \\
\end{tabular} & 0.32 & 0.29 & 0.29 & 0 & & & & & & & & & \\
\hline 24 & 0.42 & 0.38 & 0.35 & 0.41 & 0.41 & 0.27 & 0.32 & 0.32 & 0.29 & 0.39 & 0.27 & 0.38 & 0.36 & 0.3 & 0.32 & 0.3 & 0.3 & 0.3 & 0.26 & 0.35 & 0.29 & 0.32 & 0.3 & 0 & & & & & & & & \\
\hline 25 & 0.39 & 0.32 & 0.35 & 0.32 & 0.32 & 0.36 & 0.47 & 0.29 & 0.32 & 0.36 & 0.33 & 0.35 & 0.24 & 0.3 & 0.29 & 0.24 & 0.24 & 0.21 & 0.29 & 0.26 & 0.26 & 0.23 & 0.27 & 0.3 & 0 & & & & & & & \\
\hline 26 & 0.42 & 0.23 & 0.44 & 0.32 & 0.32 & 0.3 & 0.41 & 0.26 & 0.35 & 0.3 & 0.36 & 0.29 & 0.33 & 0.27 & 0.38 & 0.33 & 0.3 & \begin{tabular}{l|}
0.3 \\
\end{tabular} & 0.32 & 0.29 & 0.26 & 0.26 & 0.27 & 0.33 & 0.3 & 0 & & & & & & \\
\hline 27 & 0.35 & 0.21 & 0.45 & 0.33 & 0.3 & 0.32 & 0.42 & 0.27 & 0.33 & 0.29 & 0.38 & 0.18 & 0.32 & 0.2 & 0.33 & 0.23 & 0.32 & \begin{tabular}{|l|}
0.35 \\
\end{tabular} & \begin{tabular}{|l|}
0.33 \\
\end{tabular} & \begin{tabular}{l|l}
0.33 \\
\end{tabular} & 0.3 & 0.27 & 0.26 & 0.35 & 0.29 & 0.2 & 0 & & & & & \\
\hline 28 & 0.38 & 0.27 & 0.3 & 0.3 & 0.33 & 0.32 & 0.45 & 0.33 & 0.39 & 0.38 & 0.35 & 0.3 & 0.26 & 0.29 & 0.36 & 0.26 & 0.29 & 0.26 & 0.24 & 0.27 & 0.24 & 0.27 & 0.38 & 0.32 & 0.23 & 0.32 & 0.27 & 0 & & & & \\
\hline 29 & 0.33 & 0.29 & 0.35 & 0.35 & 0.32 & 0.36 & 0.35 & 0.26 & 0.29 & 0.15 & 0.24 & 0.26 & 0.3 & 0.18 & 0.23 & 0.27 & 0.33 & \begin{tabular}{l|}
0.3 \\
\end{tabular} & \begin{tabular}{|c|}
0.38 \\
\end{tabular} & 0.23 & 0.35 & 0.38 & 0.3 & 0.36 & 0.27 & 0.33 & 0.29 & 0.29 & 0 & & & \\
\hline 30 & 0.35 & 0.3 & 0.33 & 0.33 & 0.39 & 0.38 & 0.39 & 0.33 & 0.3 & 0.26 & 0.23 & 0.42 & 0.35 & 0.23 & 0.21 & 0.32 & 0.26 & 0.29 & 0.36 & \begin{tabular}{l|l|}
0.27 \\
\end{tabular} & \begin{tabular}{|l|}
0.27 \\
\end{tabular} & 0.39 & 0.35 & 0.32 & 0.26 & 0.38 & \begin{tabular}{|l|}
0.36 \\
\end{tabular} & \begin{tabular}{|l|}
0.36 \\
\end{tabular} & \begin{tabular}{|l|}
0.26 \\
\end{tabular} & 0 & & \\
\hline 31 & 0.27 & 0.26 & 0.35 & 0.29 & 0.32 & 0.36 & 0.32 & 0.26 & 0.2 & 0.24 & 0.27 & 0.2 & 0.27 & 0.18 & 0.17 & 0.24 & 0.3 & 0.21 & \begin{tabular}{|l|}
0.41 \\
\end{tabular} & 0.29 & 0.26 & 0.35 & 0.39 & 0.3 & 0.33 & 0.33 & \begin{tabular}{|l|}
0.32 \\
\end{tabular} & \begin{tabular}{|l|}
0.32 \\
\end{tabular} & \begin{tabular}{|l|}
0.21 \\
\end{tabular} & \begin{tabular}{|l|}
0.26 \\
\end{tabular} & 0 & \\
\hline 32 & 0.36 & 0.29 & 0.41 & 0.29 & 0.35 & 0.27 & 0.41 & 0.23 & 0.32 & 0.36 & 0.33 & 0.23 & 0.3 & 0.3 & 0.29 & 0.3 & 0.39 & \begin{tabular}{|l|}
0.33 \\
\end{tabular} & \begin{tabular}{l|l}
0.26 \\
\end{tabular} & 0.29 & \begin{tabular}{l|l|}
0.23 \\
\end{tabular} & 0.2 & 0.21 & 0.33 & 0.3 & 0.21 & \begin{tabular}{|l|}
0.26 \\
\end{tabular} & $\begin{array}{ll}0.29 \\
\end{array}$ & \begin{tabular}{l|l}
0.3 \\
\end{tabular} & \begin{tabular}{|l|l|}
0.38 \\
\end{tabular} & 0.3 & 0 \\
\hline
\end{tabular}

Note: The numbers indicate the mango cultivars as under: $1=$ Faiz Kareem, $2=$ Anwar Ratole, $3=$ Chaunsa, $4=$ Taimooria, $5=$ Kala Chaunsa, $6=$ Sanglakhi, $7=$ Sufaid Chaunsa, $8=$ Neelum, 9= Late Ratole No 12, 10= Alphonso, 11= Langra, 12= Yakta, 13= Dusehri, 14= Sindhri, 15= Fajri, 16= New Sindhri, 17= Lahootia, 18= Sobhey de Ting, 19= Began Palli, 20= Keitt, 21 = Tommy Atkins, 22= Kensington Pride, 23= Maya, 24= Swarnarekha, 25= Haider Shah, 26= Totapari, 27= Collector, 28= Zardalu, 29= Pope, 30= Sensation, $31=$ Malda and 32= Haden 
Table-3. Number of alleles amplified, allele frequency and PIC values of the selected SSR primer pairs.

\begin{tabular}{lccc}
\hline Marker & No. of alleles & Allele frequency & PIC value \\
\hline Micir-5 & 2 & $0.719,0.281$ & 0.404 \\
Micir-6 & 2 & $0.5,0.5$ & 0.5 \\
Micir-14 & 2 & $0.25,0.75$ & 0.375 \\
Micir-16 & 2 & $0.093,0.907$ & 0.168 \\
Micir-22 & 2 & $0.25,0.75$ & 0.375 \\
Micir-25 & 2 & $0.157,0.843$ & 0.265 \\
Micir-33 & 2 & $0.219,0.781$ & 0.342 \\
Mishrs-48 & 2 & $0.219,0.781$ & 0.342 \\
Mishrs-21 & 2 & $0.312,0.688$ & 0.429 \\
Mishrs-22 & 2 & $0.75,0.25$ & 0.375 \\
Mishrs-36 & 2 & $0.625,0.375$ & 0.469 \\
\hline
\end{tabular}

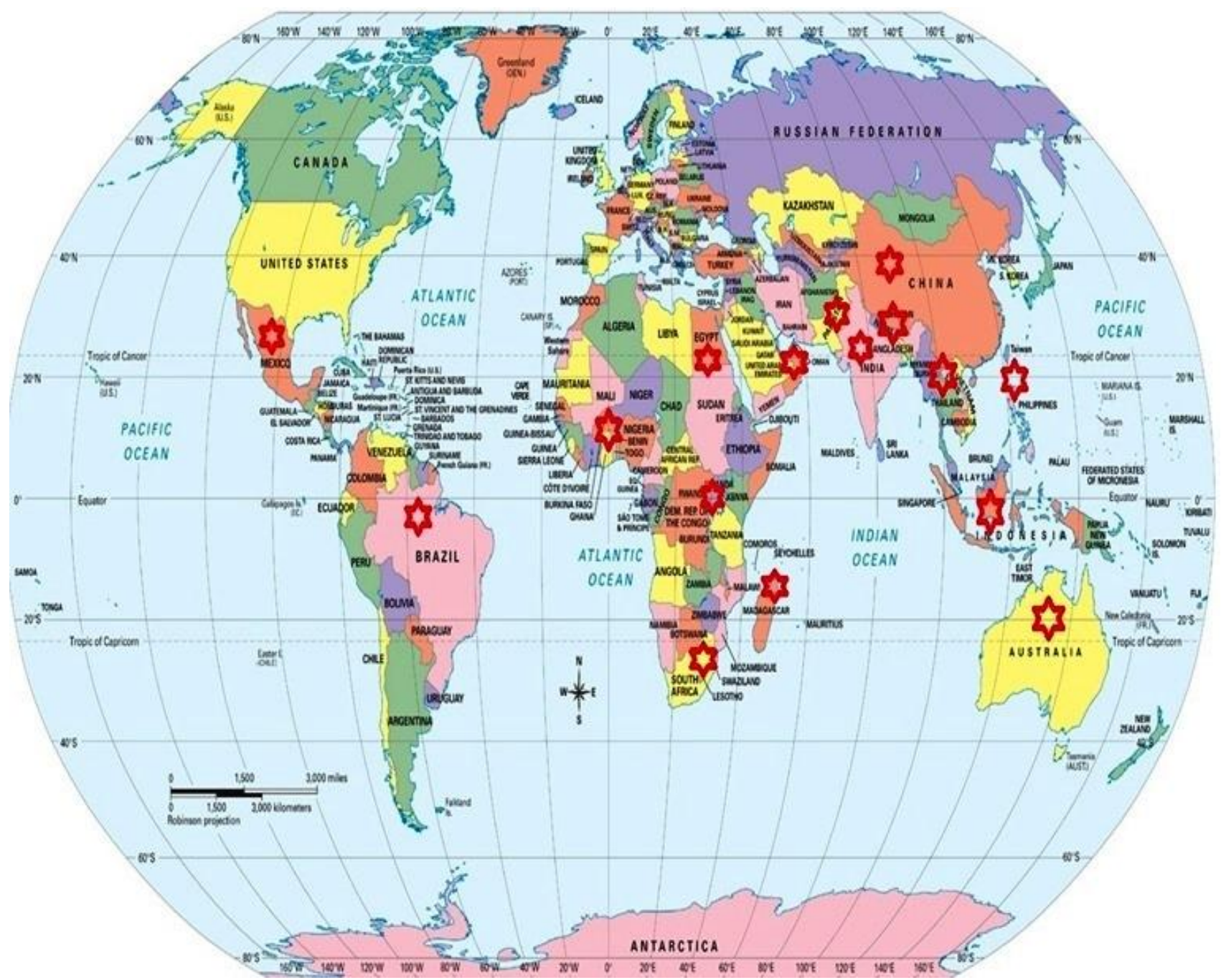

Figure-1. Countries (indicated by asterisk) producing substantial mango production worldwide. 


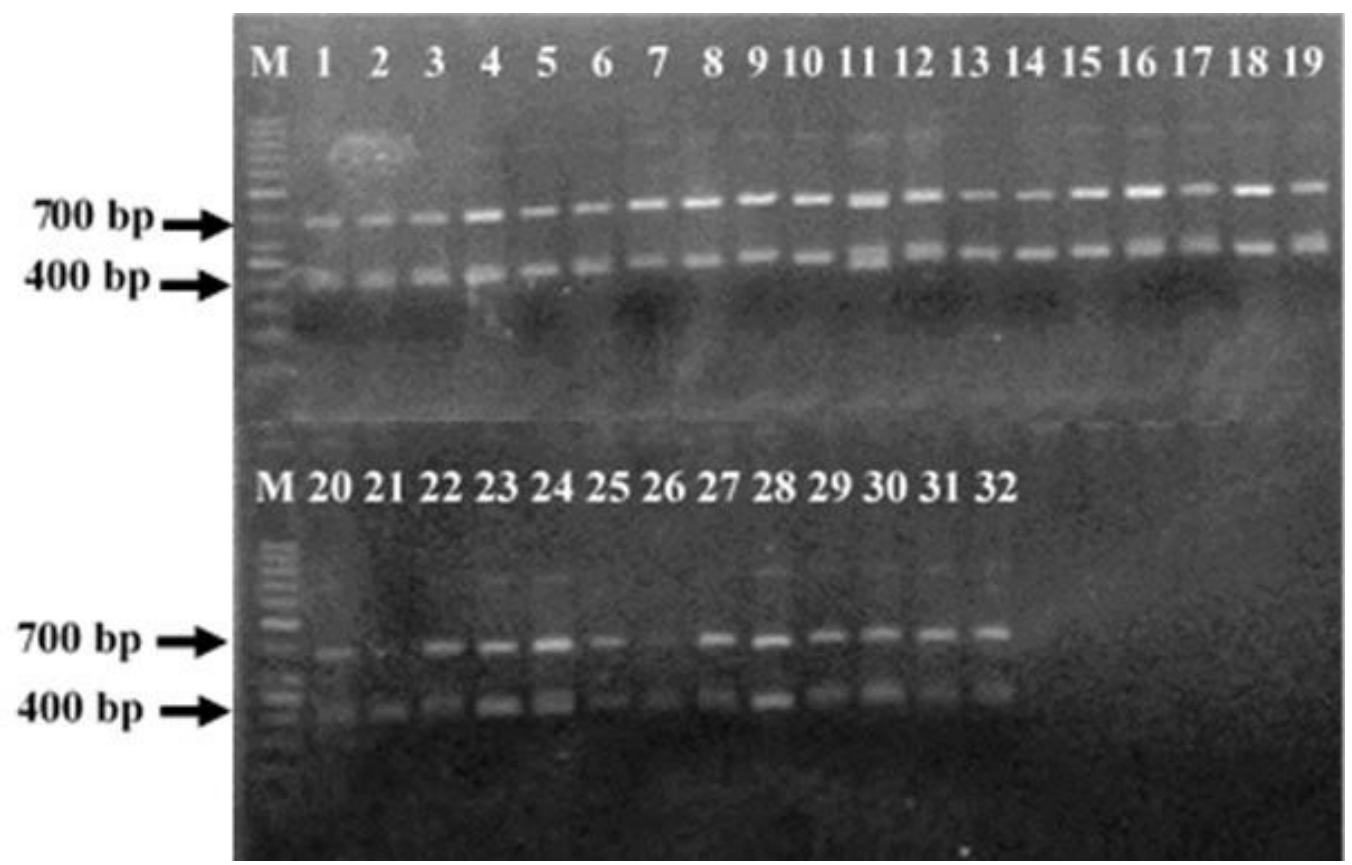

Fig. 2. SSR profile of mango germplasms generated by primer Micir 30 (M=500 bp ladder, 1 to 32 mango genotypes)

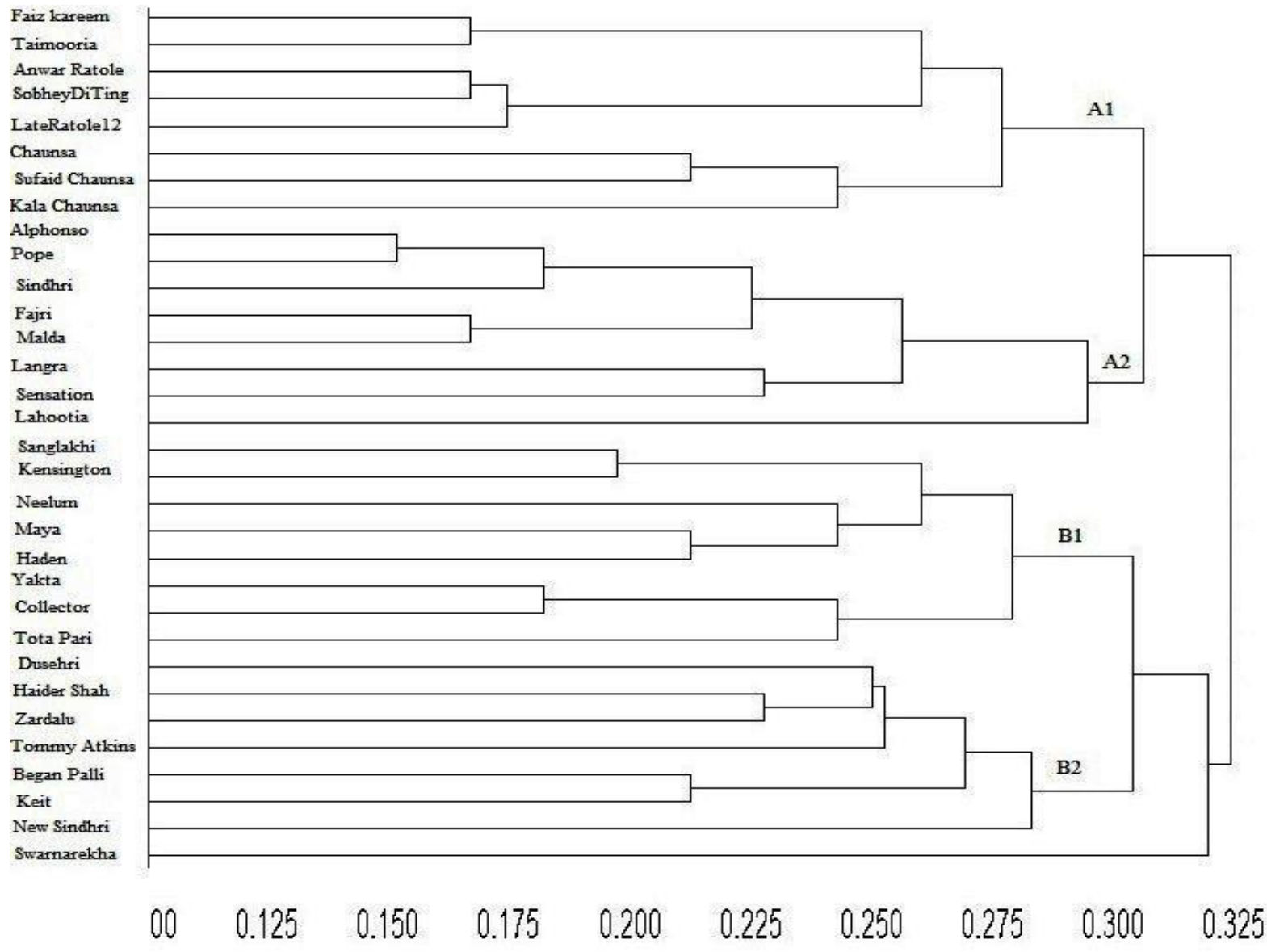

Figure-3. Dendrogram of 32 mango genotypes-cultivars based on UPGMA analysis using Euclidean dissimilarity matrix. 
Acknowledgements: The authors acknowledge the support of Plant Genomics \& Mol Breeding Labs, National Institute for Biotechnology \& Genetic Engineering (NIBGE) for extending lab facilities for conducting the SSR analysis.

\section{REFERENCES}

Abou-Ellail, M., H.M. El-Shabrawi, M.A. Matter, I.A. Usama, H.A. Ghareeb and E.A. Eissa (2014). Appraisal of biochemical and genetic diversity of mango cultivars using molecular markers. Afr. J. Biotechnol. 13: 2796-2806.

Ab Razakm S., N.H.E.N. Azman, S.N. Ismail, M.F.M. Yusof, M.A.T. Ariffin, Z.H.M Sabdin, M.H.M. Hassan, K.H. Nasir, M.A. Sani and N. Abdullah (2019). Assessment of diversity and population structure of mango (Mangifera indica L.) germplasm based on microsatellite (SSR) markers. Aust. J. Crop Sci. 13(02):315-320.

Ahmad I., M. Rahman, N. Tabbasam, Y. Zafar, R. Anwar and A.U. Malik (2007). 'Faiz Kareem': a new mango cultivar. In: A.U. Malik, M.A. Pervaiz, K. Ziaf, editors. Proceedings of the first International Conference on Mango and Date Palm, Culture and Export. Faisalabad, Pakistan: Institute of Horticultural Sciences, University of Agriculture, pp. 54.

Anderson J.A., G. Churchill, J.E. Autrique, S.D. Tanksley and M.E. Sorrells (1993). Optimizing parental selection for genetic linkage maps. Genome 36: 181-186.

Bally I.S.E., G.C. Graham and R.J Henry (1996). Genetic diversity of Kensington mango in Australia. Aust. J. Exp. Agric. 36: 243-247.

Baloch M.K. and F. Bibi (2012). Effect of harvesting and storage conditions on the post-harvest quality and shelf life of mango (Mangifera indica L.) fruit. S. Afr. J. Bot. 83: 109-116.

Chowdhury M.A., V. Vandenberg and T. Warkentin (2002). Cultivar identification and genetic relationship among selected breeding lines and cultivars in chick pea (Cicer arietinum L.). Euphytica 127: 317-325.

Doyle J.J. and J.L. Doyle (1987). A rapid DNA isolation procedure for small quantities of fresh leaf tissue. Phytochem. Bull. 19:11-15.

El Kheshin, M.A., H. A. Sayed and A. M. Abd Allatif. (2016). Morphological and molecular analysis of genetic diversity among Some 'Sukkary' mango (Mangifera indica L.) genotypes. J. Hort. Sci. Ornam. Plants 8 (1): 01-10, 2016

Galvez-Lopez D, S. Hernandez-Delgado, M. GonzalezPaz, E.N. Becerra-Leor, M. Salvador-Figueroa and N. Mayek-Perez (2009). Genetic analysis of mango landraces from Mexico based on molecular markers. Plant Genet. Resour. 7:244251.

Garcia A.A.F., L.L. Benchimol, A.M.M Barbosa, I.O. Geraldi, C.L. Souza and A.P. de Souza (2004). Comparison of RAPD, RFLP, AFLP and SSR markers for diversity studies in tropical maize inbred lines. Genet. Mol. Biol. 27:579-588.

Gutierrez, O.A., S.B.S. Basu, S. Saha, J.N. Jenkins, D.B. Shoemaker, C.L. Cheatham and J.C. Jr. McCarty. (2002). Genetic distance among selected cotton genotypes and its relationship with F performance. Crop Sci. 42: 1841-1847.

Hasan, M., F. Seyis, A.G. Badani, J. Pons-Kuhnemann, W. Friedt, W. Luhs and R.J Snowdon (2006). Analysis of genetic diversity in the Brassica napus L. gene pool using SSR markers. Genet. Resour. Crop Evol. 53:793-802.

Jain, S., R.K. Jain and S.R. McCouch (2004). Genetic analysis of Indian aromatic and quality rice (Oryza sativa L.) germplasm using panels of fluorescently-labeled microsatellite markers. Theor. Appl. Genet. 109: 965-977.

Jena, R.C., K.C. Samal, P.K. Chand and B.K Das (2010). Molecular Characterization of 12 mango germplasm using RAPD markers. Plant Tissue Cult. Biotechnol. 20:91-99.

Jha S.K., S. Sethi, M. Srivastav, A. Dubey, R.R. Sharma, D.V.K. Samuel and A.K. Singh (2010). Firmness characteristics of mango hybrids under ambient storage. J. Food Eng. 97:208-212.

Kalivas, A., F. Xanthopoulos, O. Kehagia and A.S. Tsaftaris (2011). Agronomic characterization, genetic diversity and association analysis of cotton cultivars using simple sequence repeat molecular markers. Genet. Mol. Res. 10: 208217.

Kebede, M., D. Ehrich, P. Taberlet, S. Nemomissa and C. Brochmann (2007). Phylogeography and conservation genetics of a giant lobelia (Lobelia giberroa) in Ethiopian and tropical East African mountains. Mol. Ecol. 16: 1233-1243.

Kumar, M., V. Ponnuswami, P. Nagarajan, P. Jeyakumar and N. Senthil (2013). Molecular characterization of ten mango cultivars using simple sequences repeat (SSR) markers. Afr. J. Biotechnol. 47:6568-6573.

Liu, S., S. Saha, D. Stelly, B. Burr and R.G. Cantrell (2000a). Chromosomal assignment of microsatellite loci in cotton. J. Hered. 91: 326332.

Liu, S., R.D. Cantrell, J. C. McCarty and J.Mc.D. Stewart (2000b). Simple sequence repeat-based assessment of genetic diversity in cotton race stock accessions. Crop Sci. 40: 1459-1469.

Macaulay, M., L. Ramsay, W. Powell and R. Waugh (2001). A representative, highly informative 
'genotyping set' of barley SSRs. Theor. Appl. Genet. 102: 801-809.

Majumder, D.A.N., L. Hassan, M.A. Rahim and M.A. Kabir (2013). Genetic diversity in mango (Mangifera indica 1.) through multivariate analysis. Bangladesh J. Agric. Res. 38: 343-353.

Masood, A., S. Saeed, S.F.D. Silveira, C.N. Akem, N. Hussain and M. Farooq (2011). Quick decline of mango in Pakistan: survey and pathogenicity of fungi isolated from mango tree and bark beetle. Pakistan J. Bot. 43: 1793-1798.

Masi, P., P.L.S. Zeuli and P. Donini (2003). Development and analysis of multiplex microsatellite markers sets in common bean (Phaseolus vulgaris L.). Mol. Breeding 11: 303313.

Maqbool, M. and A.U. Malik (2008). Anti-sap chemicals reduce sapburn injury and improve fruit quality in commercial mango cultivars. Int. J. Agric. Biol. 10:1-8.

Mitra, S. K (2016). Mango production in the worldpresent situation and future prospect. Acta Hortic. 1111: 287-296.

Nayak, D. (2010). Characterization of mango hybrids for fruit quality traits. PhD, PG School, IARI, New Delhi.

Nazish, T., G. Shabbir, A. Ali, S. Sami-ul-Allah, M. Naeem, M. Javed, S. Batool, H. Arshad, S.B. Hussain, K. Aslam, R. Seher, M. Tahir and M. Baber. (2017). Molecular diversity of Pakistani mango (Mangifera indica L.) varieties based on microsatellite markers. Genet. Mol. Res. 16 (2): gmr16029560

Nei, M. and W.H. Li (1979). Mathematical model for studying genetic variation in terms of restriction endonucleases. Proc Natl. Acad. Sci. USA 76: 5269-5273.

Oloka, B.M., J. Lamo, P. Rubaihayo, P. Gibson and J. Vorster (2015). The use of multiplexed simple sequence repeat (SSR) markers for analysis of genetic diversity in African rice genotypes. Afr. J. Biotechnol. 14: 1533-1542.

Pandit, S.S., S. Mitra, A.P. Giri, K.H. Pujari, B.P Patil, N.D. Jambhale and V.S Gupta (2007). Genetic diversity analysis of mango cultivars using inter simple sequence repeat markers. Curr. Sci. 93: 1135-1141.

Pandey S.N. 1998. Mango cultivars, R.P.P. (ed.). International Book Distributing Company, Lukhnow, India.

Pejic, I., P. Ajmone-Marsan, M. Morgante, V. Kozumplick, P. Castiglioni, G. Taramino and M. Motto (1998). Comparative analysis of genetic similarity among maize inbred lines detected by RFLPs, RAPDs, SSRs, and AFLPs. Theor. Appl. Genet. 97:1248-1255.
Peng, J.H. and N.L.V. Lapitan (2005). Characterization of EST-derived microsatellites in the wheat genome and development of eSSR markers. Funct. Integr. Genom. 5: 80-96.

Pruthvish, P. and B.K. Chikkaswamy (2016) Genetic diversity and relationships among mango varieties using RAPD molecular markers. Int. J. Curr. Microbiol. App. Sci. 5(1): 778-787.

Rajwana, I.A., I.A. Khan, A.U. Malik, B.A. Saleem, A.S. Khan, K. Ziaf, R. Anwar and M. Amin (2011). Morphological and biochemical markers for varietal characterization and quality assessment of potential indigenous mango (Mangifera indica) germplasm. Int. J. Agric. Biol. 13:151158.

Rajwana, I.A., N. Tabbasam, A.U. Malik, S.A. Malik, M. Rahman and Y. Zafar (2008). Assessment of genetic diversity among mango (Mangifera indica L.) genotypes using RAPD markers. Sci. Hortic. 117:297-301.

Rahman, M., T. Shaheen, N. Tabbasam, M.A. Iqbal, M. Ashraf, Y. Zafar and A.H. Paterson (2012). Cotton genetic resources- A review. Agron. Sustain. Dev. 32: 419-432.

Rahman, M., T. Yasmin, N. Tabassum, I. Ullah, M. Asif and Y. Zafar (2008). Studying the extent of genetic diversity among Gossypium arboreum L. genotypes/cultivars using DNA fingerprinting. Genet. Resour. Crop Ev. 55: 331-339.

Rahman, M., D. Hussain and Y. Zafar (2002). Estimation of genetic divergence among elite cotton (Gossypium hirsutum L.) cultivars by DNA fingerprinting technology. Crop Sci. 42: $2137-$ 2144.

Ravishankar, K.V., P. Bommisetty, A. Bajpai, N. Srivastava, B.H. Mani, C. Vasugi, S. Rajan and M.R. Dinesh (2015). Genetic diversity and population structure analysis of mango (Mangifera indica) cultivars assessed by microsatellite markers. Trees 29: 775-783.

Schnell, R.J., J. S. Brown, C. T. Olano, A. W. Meerow, R.J. Campbell and D.N. Kuhan (2006). Mango genetic diversity analysis and pedigree inferences for Florida cultivars using microsatellite markers. J. Am. Soc. Hortic. Sci. 131: 214-224.

Shareefa, M. (2008). DNA fingerprinting of mango (Mangifera indica L.) genotypes using molecular markers. Ph.D, P.G. School, IARI, New Delhi.

Souza, I.G.B., S.E.S. Valente,, F.B. Britto, V.A.B. de Souza and P.S.C. Lima (2011). RAPD analysis of the genetic diversity of mango (Mangifera indica) germplasm in Brazil. Genet. Mol. Res. 10: 3080-3089. 
Tabassam, N., Y. Zafar and M. Rahman (2014). Pros and cons of using genomic SSRs and EST-SSRs for resolving phylogeny of the genus Gossypium. Plant. Syst. Evol. 300: 559-575.

Thuillet, A-C, T.M. Bataillon, P. Sourdille and J.L. David (2004). Factors affecting polymorphism at microsatellite loci in bread wheat (Triticum aestivum (L.) Thell]: effects of mutation processes and physical distance from the centromere. Theor. Appl. Genet. 108: 368-377.

Vigouroux, Y., S. Mitchell, Y. Matsuoka, M. Hamblin, S. Kresovich, J.S.C. Smith, J. Jaqueth, O.S. Smith and J. Doebley (2005). An analysis of genetic diversity across the maize genome using microsatellites. Genetics 169: 1617-1630.

Viruel, M.A. and J.I. Hormaza (2004). Development, characterization and variability analysis of microsatellites in lychee (Litchi chinensis Sonn., Sapindaceae). Theor. Appl. Genet. 108: 896902.
Viruel, M.A., P. Escribano, M. Barbieri, M. Ferri and J.I. Hormaza (2005). Fingerprinting, embryo type and geographic differentiation in mango (Mangifera indica L., Anacardiaceae) with microsatellites. Mol. Breed. 15:383-393.

Yamanaka, S., F. Hosaka, M. Matsumura, Y. OnoueMakishi, K. Nashima, N. Urasaki T. Ogata M. Shoda and T. Yamamoto (2019) Genetic diversity and relatedness of mango cultivars assessed by SSR markers. Breed Sci. 69(2):332344.

Zhang, S., C. Tang, Q. Zhao, J. Li, L. Yang, L. Qie, X. Fan, L. Li, N. Zhang, M. Zhao, X. Liu, Y. Chai, X. Zhang, H. Wang, Y. Li, W. Li, H. Zhi, G. Jia and X. Diao (2014). Development of highly polymorphic simple sequence repeat markers using genome-wide microsatellite variant analysis in Foxtail millet [Setaria italica (L.) P. Beauv.]. BMC Genomics 15:78. 